(2021), 4 (1): 29-34

\title{
ERROR ANALYSIS IN PRONUNCIATION MADE BY THE ENGLISH DEPARTMENT STUDENTS AT IKIP BUDI UTOMO MALANG
}

\author{
Marsuki \\ IKIP Budi Utomo \\ zukimadurasa@gmail.com
}

\begin{abstract}
This research investigates and analizes pronunciation errors made by the students of English Education Department at IKIP Budi Utomo Malang. Errors in students' pronunciation are crucial problems among foreign language teacher, especially English teacher. This research aims at investigating and finally finding out pronunciation errors made by the English students of S-1. The subjects of the study are the S-1 English students in academic period 2019/2020 that total 40 students who took dictation course in the third semester. The data of the study are a group of students' pronunciation or speech sounds. Based on the description above, there are two important problems proposed in terms of kinds of pronunciation errors and causes of pronunciation errors. Of the data analysis carried out, it is found out that kinds and causes of pronunciation errors which are classified into significant and non-significant errors. There are four causes of pronunciation errors, namely (1) some differences of speech sounds between English and Indonesian; (2) the same phonetic features which have the different distribution between English and Indonesian; (3) interference of native language; and (4) lack of practices and exposures in English pronunciation.
\end{abstract}

Keywords: error analysis, speech sound, significant, non-significant, interference

OPendidikan Bahasa Inggris FPISH IKIP BU Malang

\section{Introduction}

It seems very obvious that errors which are made by students in the process of learning a language in the classroom have become a great concern for language teachers. These errors may occur because many students in general encounter difficulties in learning a second or target language. One of their difficulties in the learning process is how they pronounce the foreign language words correctly. This serious problem appears since they are not still familiar with the learning of the new sound system. In addition, they are influenced by their mother tongue which has been deeply implanted in them as part of their habit (Ramelan, 1988: 6). The movements of their speech organs have been set to produce the speech sounds of their own language, so it will, of course, be difficult for them to change their habit of moving their speech organs in such a way as to produce the foreign sounds. For example, many Indonesian students often produce poor pronunciation when they are speaking English. Consequently, it is quite difficult for someone else to understand and interpret what they say. To minimize and overcome these errors, English teachers often make a hard attempt to observe from all aspects what factors cause their students' difficulties in pronunciation so that they might develop their techniques of teaching English pronunciation.

Based on the discussion above, the writer of this study is very interested in studying and investigating the pronunciation errors made by the $S-1$ students of English Department at IKIP Budi Utomo Malang. Thus, the questions which have been formulated as the problems of this study are as follows:

1. What kinds of errors are made by the English Department students in pronouncing the English speech sounds? 
2. What factors cause the English Department students' errors in pronouncing the English speech sounds?

\section{THE ROLES OF ERROR ANALYSIS IN ENGLISH PRONUNCIATION}

Error analysis (EA) was developing since there were a lot of criticisms to contrastive analysis (CA) in the fact that CA has failed in designing the prediction towards the difficulties and errors made by the students on the basis of the differences of two languages and language interference. Consequently, EA objected to the assumption and practice of CA which focused its effort on the first language interference while the other factors were almost neglected. Lee (1968) argued that the first language interference (L1) was not the only factor causing learning difficulties without knowing how far the learners master the material and how the teachers teach them.

To make error analysis more accurate, Corder (1977) distinguished between mistakes and errors in definition. 'Mistakes' refers to inconsistent and unsystematic deviation which is caused by the external environment such as fatigue, emotion, tiredness, etc. While, 'errors' deals with the systematic deviation which leads to competence. Besides, errors might be classified into interlingual and intralingual errors (Krashen, 1982). Interlingual error is the interference of the first language system to the second language system, while intralingual/developmental error refers to incomplete mastery of learning the target language such as overgeneralization and failure to learn condition under which the rules apply (Richards, 1974).When students make erroneous pronunciation in learning a foreign language such as English, their common errors usually involve consonants (devoicing, substitution, etc.), vowels (lowering, monophthongization, etc), and consonant clusters. Therefore, these errors might be classified into significant and nonsignificant errors. Significant errors refer to the deviation which may change the meaning of an utterance, while nonsignificant errors lead to the deviation which does not necessarily change the meaning of an utterance. These opinions are in line with the findings of the previous researches or studies which were conducted by Djiwandono (1964) and Ma'mun (1970). Djiwandono investigated the pronunciation of the English students who come from Java, Madura, Manggarai (Flores), Larantuka (Flores) and Bali. It was found that they made erroneous pronunciation in English especially in consonants, vowels, and consonants clusters which are classified into significant and non-significant errors. Similarly, Ma'mun investigated phonological problems for Minangkabau students learning English and finally found that the similarities between English and Minangkabau phonemes make the Minangkabau students pronounce English speech sounds easily, while dissimilarities are suspected to create difficulties for Minangkabau students learning English.

\section{Research Method}

The subjects of this study are the S1 students of English Department of IKIP Budi Utomo Malang in academic year 2019/2020. It totals 40 students who take dictation course in the third semester. They of course have experienced in pronunciation since they took that course in their first semester. Based on the explanation above, the data of this study are the students' speech sounds or pronunciation. In order to have all students produce the same sounds in the same context, the writer provided a test as an instrument containing selected words and allowed them to pronounce those words twice. Those selected words contain all English consonants in all their 
orthographic positions, all English vowels and diphthongs, and also consonant clusters. Each student's pronunciation was collected by recording it with a good tape recorder. This activity of recording was conducted when the students were having dictation on Monday, December 20 ${ }^{\text {th }}, 2004$.

After the students' pronunciations were recorded, those data were then transcribed into English phonetic transcriptions by using the International Phonetic Alphabet (IPA) and then analysed on the basis of the two problems above. The kinds of errors found out will be then classified into significant errors and non-significant errors. The findings on the basis of the kinds of errors will then be stated in the percentage which is determined by the frequency of making errors compared with the whole number of occurrences of those sounds in the instrument. Thus, the results in the classification of errors would decide and conclude the factors causing the English students' errors in pronouncing the English speech sounds.

\section{Result and Discussion}

The findings of the study are grouped on the basis of the classification and causes of errors made by the S-1 English students in pronouncing the English speech sounds at IKIP Budi Utomo Malang. Those findings will be discussed in detail as follows:

\section{Classification of Errors:}

\section{Significant Errors}

Significant errors are the deviation which may change the meaning of an utterance. They involve consonants, vowels, and consonant clusters.

\subsection{Consonants}

Consonants are speech sounds which are produced with interruption or stoppage of the airstream in the mouth. The errors or deviation in consonant distribution made by the English students cover devoicing and substitution.

\subsubsection{Devoicing}

Devoicing refers to process of making voiced consonants become voiceless consonants. The students' errors in this process are as follows:

voiced blade-alveolar fricative $\longrightarrow \mathrm{zl}$ voiceless blade-alveolar fricative /s/ :

zing /zIn / becomes sing /sIn / (initial position $=35 \%$ )

cause $/ \mathrm{kPz} /$ becomes course /kO:s / $\quad($ final position $=85 \%)$

voiced labio dental fricative $\longrightarrow$ voiceless labio dental fricative /f / :

very /vErI/ becomes ferry /f ErI / (initial position $=90 \%$ )

save /seIv / becomes safe /seIf / (final position $=95 \%$ )

voiced bilabial stop /b/

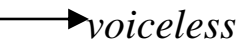

bilabial stop /p/ :

robe /roub/ becomes roup /roup / (final position $=92.5 \%)$

voiced alveolar stop $/ \mathbf{d} / \longrightarrow \longrightarrow$ oiceless alveolar stop /t/ :

bid /bId / becomes bit /bIt / (final position $=95 \%)$

voiced velar stop $/ \mathrm{g} / \longrightarrow$ voiceless velar stop $/ \mathbf{k} /$ :

bag /bæg/ becomes back /bæk/ (final position $=92.5 \%$ )

\subsubsection{Substitution}

voiceless dental fricative $\longrightarrow / \boldsymbol{\theta} /$ voiceless alveolar stop /t/ :

thin /0In / becomes tin /tIn / (initial position $=52.5 \%$ )

faith /feIt / becomes fate /feIt / (final position $=67.5 \%)$

voiced dental fricative $\longrightarrow / \delta /$ voiceless alveolar stop /d/ :

they / $\mathrm{deI} /$ becomes day /deI / (initial position $=37.5 \%$ )

voiceless palato-alveolar fricative /s / voiceless blade-alveolar fricative /s/ :

shin /JIn / becomes sin /sIn / (initial position $=25 \%$ ) 
push /puJ/ becomes puss /pus/ (final position $=17.5 \%$ )

\subsection{Vowels}

Vowels are speech sounds which are produced without interruption or stoppage of airstream in the mouth. The errors or deviation in vowel distribution made by the English students cover lowering, monophthongization, and substitution.

\subsubsection{Lowering}

unrounded close front vowel $\overrightarrow{\mathrm{i}}: / \longrightarrow$ unrounded half close front vowel /// :

eat /i:t/ becomes it /It/ (27.5\%)

feel /fi:1/ becomes fill /fIl / $(37.5 \%)$

rounded close back vowet u:/ rounded half-close to close back vowel $/ \mathbf{u} /$ :

fool /fu:1/ becomes full /ful/ (30\%) food /fu:d / becomes foot /fut / $(27.5 \%)$

\subsubsection{Monophthongization}

front-front closing half diphthong $/ \mathbf{e I} \longrightarrow$ unrounded half close front vowel /// : tail /teIl/ becomes till /tIl/ (87.5\%) fail /feIl/ becomes fill /fIl/ (82.5\%) back-back closing half diphthong /ou/ rounded open back vowel /D/ :

coke /kouk / becomes cock / kDk / $(27.5 \%)$

coast /koust / becomes cost /kOst / (20\%)

\subsubsection{Substitution}

unrounded open to half-open front vowel /æ/ unrounded half-close vowel /E/ : bad /bæd/ becomes bet /bEt/ $(72.5 \%)$

\section{Consonant Clusters}

/dgd / /t/ in final position: aged /eIdzd / becomes it /It/ (17.5\%) $/ \overline{\mathbf{n d}} / \longrightarrow \quad / \mathrm{n} /$

in final position:

manned /mænd / becomes man /mæn / $(70 \%)$ in final position<smiles>CCC</smiles>

packed /pækt / becomes pack /pæk/ $(100 \%)$

The examples of errors in consonant, vowel, and consonant clusters above could make someone else misunderstand because they change the meanings of the utterance.

\section{Non-Significant Errors}

Non-significant errors are the deviation which does not necessarily change the meaning of an utterance. They include consonants, vowels, and consonant clusters as follows:

\subsection{Aspiration and Non-Aspiration:}

Aspiration is a vigorous expulsion of air which can be detected after the explosion of the consonant and before the beginning of the vowels. Aspiration occurs after the consonants $/ \mathrm{p}, \mathrm{t} . \mathrm{k} /$, namely $\left[\mathrm{p}^{\mathrm{h}}, \mathrm{t}^{\mathrm{h}}, \mathrm{k}^{\mathrm{h}}\right]$ in the initial and medial positions in English. Unfortunately, the English students make errors by pronouncing the non-aspirated consonants to the aspirated consonants. These errors cannot change the meaning of the utterances such as:

pet $\quad\left[\mathbf{p}^{\mathrm{h}} \mathcal{E t}\right]$ pronounced $\quad[\mathbf{p E t}]$ $(87.5 \%)$

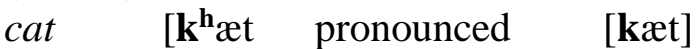
$(92.5 \%)$

took [ $\left.\mathbf{t}^{\mathrm{h}} \mathrm{uk}\right]$ pronounced [tuk] $\stackrel{(80 \%)}{\longrightarrow}$

\subsection{Substitution in Consonants and Vowels \\ chair / tfEӘ / becomes /cEУ / $(75 \%)$ \\ men /mEn / becomes /mӘn/ $(12.5 \%)$}

The examples above belong to the non-significant errors which do not necessarily change the meaning of the utterances, but those sounds look unusual and strange to the English native speakers. 


\section{B. Causes of the Errors:}

Based on the results of the students' errors in English pronunciation above, the factors causing the students' errors in pronouncing English speech sounds may be determined and concluded. There are at least four factors which cause the English students' errors in pronouncing English speech sounds at IKIP Budi Utomo Malang. Those causes of the errors are as follows:

First, the students' errors in pronouncing the English speech sounds are caused by some distinctive speech sounds (consonants and vowels) between their native language and the target language. It implies that there are some English phonemes which are not found in Indonesian and their local languages such as $/ \mathbf{t} /, / \mathbf{d} \mathbf{J} /, / \mathbf{J} /, / \mathbf{v} /, / \mathbf{Z} /, / / \boldsymbol{\theta} /, / \delta /$, /ag/, etc. As a result, the students have troubles to pronounce them. Second, the students' errors are caused by the sounds which have the same phonetic features between English and Indonesian but differ in their distribution. For example, the voiced stop consonants /b, d, g / in English might occur in all positions, while in Indonesia they can occur in initial and medial positions not in final position. Consequently, the English students will pronounce 'robe' /roub / with /roup /, ' bid' /bId / with /bIt/, ' bag' /bæg / with /bæk / . Third, The students' errors are caused by phonemic interference. Since the students have possessed the old habit of speaking their first language, their effort to learn English might encounter the serious problems due to the interference in their mother tongue. Thus, when they try to pronounce English words, they often make errors in pronunciation. At last, the students' errors are also caused by lack of oral practice in pronunciation and lack of exposures which makes them unable to imitate the correct sounds.

\section{Conclusion}

On the basis of the explanation above, this study has found kinds and causes of the English students' errors in pronouncing the English speech sounds at IKIP Budi Utomo Malang. Those errors made by the English students are classified into significant and nonsignificant errors. The significant errors involve the deviation of consonants (devoicing and substitution), vowels
Figure 1. Level of Student Participation in Discussion Activities

(lowering, monophthongization, and substitution), and consonant clusters. These errors change the meanings of the utterances. While the non-significant errors are deviation of the speech sounds which does not necessarily change the meanings of the utterances. Besides, it has been found that there are at least four causes of the students' errors, namely (1) some distinctive speech sounds between English and Indonesian, (2) the same 
phonetic features with different distribution of the two languages, (3) the first language interference, and (4) lack of oral practice and exposures in English pronunciation.

These findings will become significant suggestion and input for the teacher who is teaching English pronunciation (1) to determine the sequences of the teaching materials in pronunciation, (2) to decide and give the emphasis of explanation and exercises such as oral practice, repetition, and imitation, (3) to give remedies in teaching and exercises, (4) to select the second language specification for proficiency test in teaching and learning English pronunciation (Sridhar, 1980: 103). That is why, it is expected that the teacher of English pronunciation will pay a serious attention to improve the techniques of teaching pronunciation so that his students could be free of their difficulties in pronouncing the foreign sounds. Consequently, the students will have a teacher of the English pronunciation as a good model and ultimately get successful in producing the foreign sounds correctly in the same way as the native speakers.

\section{References}

Baradja, M.F. (1990). Kapita Selekta Pengajaran Bahasa. Penerbit IKIP Malang.

Corder, S. P. (1977). Introducing Applied Linguistics. Penguin Books.

Daniel, J. (1956). An outline of the English Phonetics. Cambridge: W. Heffer and Sons Ltd.

Daniel, J. (1956). The Pronunciation of English. Cambridge: the University Press.

Djiwandono, M. S. (1964). A Study of Pronunciation Deviation of English Sound Made by Indonesian Studentss with Different Linguistic Background.
IKIP Malang. Unpublished Thesis.

Kenneth, L. P. (1961). Phonetics. An Arbor: The University of Michigan Press.

Krashen, S. D. (1982). Principles and Practice in Second Language Acquisition, Oxford: Pergamon.

Lado, R. (1975). Linguistic Across Cultures. An Arbor: The University of Michigan Press.

Lee, W. R. (1968). Thoughts on Contrastive Linguistics in the Context of Foreign Language Teaching. In James E. Alatis, ed. $19^{\text {th }}$ Annual Round Table, 185194. Washington: Georgetown University Press.

Ma'mun, M. N. (1970). Some Phonological Problems for Minangkabau Students Learning English. IKIP Malang. Unpublished Thesis.

Ramelan. (1988). English Phonetic. IKIP Semarang Press.

Richards, J, ed. (1975). Errors Analysis. London: Longman.

Sridhar, S. N. (1980). Contrastive Analysis, Error Analysis and Interlanguage. In Kenneth Croft, ed. Readings on English as a Second Language. Cambridge, Mass.:WinthropPublishers,Inc. 